\title{
СРЕДСТВА СИНТАКСИЧЕСКОЙ СТИЛИСТИКИ В ЗАГОЛОВКАХ РОССИЙСКИХ ЭЛЕКТРОННЫХ СМИ
}

\section{THE MEANS OF SYNTAX STYLISTICS IN THE HEADLINES OF THE RUSSIAN ELECTRONIC MEDIA}

O. Kuzina

Summary: The article presents an analysis of the main means of syntactic stylistics that are found in modern Russian electronic media, using the example of Gazeta.Ru. The article reveals the appeal of journalists to such constructions (means) as rhetorical questions and exclamations, question-and-answer constructions, ellipsis, rows of homogeneous members, truncated syntactic constructions, appeals to the reader, parcelling, syntactic parallelism, etc. The conclusion is made about the significant influence of the expressive syntax on the perception of the reader, about the importance of his means in the case of the transfer of actual information by the author to the addressee.

Keywords: syntax, syntactic stylistics, electronic media, heading, rhetorical question, ellipsis, syntactic parallelism.

\author{
Кузина Ольга Васильевна \\ К.филол.н., дочент, Гжельский государственный \\ университет \\ kuzina85@bk.ru
}

Аннотация: В статье представлен анализ основных средств синтаксической стилистики, которые встречаются в современных российских электронных СМИ, на примере «Газеты.Rи». Выявлена апелляция журналистов к таким конструкциям (средствам), как риторические вопросы и восклицания, вопросно-ответные конструкции, эллипсис, ряды однородных членов, усечённые синтаксические конструкции, обращения к читателю, парцелляция, синтаксический параллелизм и др. Делается вывод о значительном влиянии экспрессивного синтаксиса на восприятие читателя, о важности его средств в случае передачи автором адресату актуальной информации.

Ключевые слова: синтаксис, синтаксическая стилистика, электронные СМИ, заголовок, риторический вопрос, эллипсис, синтаксический параллелизм. $\ni$ лектронные средства массовой информации (СМИ), являющиеся в настоящий момент значимыми конститутиентами коммуникативного пространства, нацелены на оказание разнопланового воздействия на аудиторию, с чем связаны особенности используемых в их текстах языковых единиц, в том числе синтаксических конструкций. Синтаксис представляет собой важное организующее начало текста, при этом в качестве синтаксических средств могут использоваться элементы разговорного синтаксиса [6], явления, связанные с порядком слов [5] и т.д. Наибольшую эффективность с точки зрения воздействия на адресата текст СМИ приобретает, если в нём используются средства экспрессивного синтаксиса, или синтаксической стилистики. Предметом изучения синтаксической стилистики является «смысловое, стилистическое использование единиц синтаксического уровня языка» [4, с. 145], когда данные единицы перестают быть просто синтаксическими, а становятся трансляторами смысла, идеи, эмоции. Языковыми средствами синтаксической стилистики называются «парцелляция, градация, ряды однородных членов предложения, инверсия, эллипсис, номинативные предложения» и др. [Там же, с. 146]. Те или иные средства экспрессивного синтаксиса регулярно становятся предметом исследования лингвистов [1; 3 и др.], однако необходимо более внимательно взглянуть на заголовки электронных российских СМИ с точки зрения синтаксической стилистики.
Цель статьи - выявить основные типы синтаксических конструкций (средств), которые играют важную роль в языковом оформлении заголовков российских электронных СМИ. Исследование проводилось на материале электронного медиаиздания «Газета.Ru» [2], стабильно отмечаемого в различных рейтингах как популярное среди читателей.

Наше исследование показало, что наиболее востребованными средствами синтаксической стилистики в анализируемом материале являются:

- риторические вопросы, то есть вопросы, которые не требуют ответа: «Что, съели?» (03.12.2021);

- риторические восклицания: «B Париж! В Париж!» (23.10.2021), «Долой мыслепреступления!» (27.09.2021);

- вопросно-ответные конструкции, при использовании которых вопрос обычно содержится в заголовке, а ответ - в тексте статьи: «Люди или песики?» (03.11.2021). В редких случаях оба компонента входят в заголовок: «Свобода слова? Дайте две!» (06.10.2021);

- эллипсис как пропуск какого-то элемента текста, на месте которого обычно ставится тире: «Экспертам - экспертизу» (26.11.2021);

- ряды однородных членов, воздействующая сила которых увеличиваются, если в них включаются логически несопоставимые явления: «Изобрета- 
тели колеса, коммуналки и сексуальных оргий» (21.10.2021), в том числе с отрицательным союзом ни...ни: «Ни терки, ни воронки, ни мочалки» (16.10.2021). С помощью рядов однородных членов заголовок вызывает интерес к содержанию статьи, в котором читатель стремится декодировать парадоксальный смысл загадочного перечисления;

- усечённые синтаксические конструкции, в которых опущенной оказывается последняя часть, а читатель должен догадаться, о какой фразе идёт речь, и продолжить её. Например: «Авторка с возу» (24.11.2021). В данном примере закодирована пословица «Баба с возу - кобыле легче», кроме того, трансформированная при помощи феминитива авторка;

- обращения к читателю, как риторические, так и имитирующие диалог: «А знаешь, Иванова забрали» (16.11.2021);

- парцелляция, которая особенно эффектно выглядит в пространстве заголовка, и так отличающегося краткостью: «Пелевин. Просто уже все» (17.10.2021);

- синтаксический параллелизм, то есть использование конструкций с одинаковой структурой, но разным лексическим наполнением: «Семья как ярмо. И семья как роскошь» (08.11.2021) и др.

Функционируя в заголовках публикаций, данные синтаксические средства и конструкции привлекают внимание читателей не только к заголовку, но и к самой публикации, шире - к поднимаемой в ней проблеме. По нашим наблюдениям, к средствам синтаксической стилистики авторы прибегают чаще в тех случаях, когда поднята значимая, актуальная проблема.

Итак, средства синтаксической стилистики оказываются чрезвычайно востребованными при конструировании журналистами заголовков современных электронных СМИ. Набор синтаксических конструкций (средств), которыми оперируют современных журналисты, очень значителен, включает риторические вопросы и восклицания, вопросно-ответные конструкции, эллипсис, ряды однородных членов, усечённые синтаксические конструкции, обращения к читателю, парцелляция, синтаксический параллелизм и т.п. Разнообразие синтаксических моделей, выбираемых авторами для заголовков, говорит о том внимании, которое журналисты уделяют синтаксической стилистике. Экспрессивная синтаксическая конструкция, особенно если она трансформирует обычное построение фразы (а именно так в большинстве случаев и происходит), привлекает внимание читателя и побуждает его перейти по гиперссылке и ознакомиться с информацией, которая содержится в самой статье. заголовок играет информативную, привлекающую внимание, экспрессивную функции.

Перспективы исследования состоят в анализе конкретных (отдельных) средств синтаксической стилистики в языке СМИ и выявлении их зависимости от содержания публикации.

\section{ЛИТЕРАТУРА}

1. Вяткина С.В., Чу Ц. Конструкции экспрессивного синтаксиса в текстах русских и китайских электронных СМИ // Актуальные проблемы гуманитарного знания в техническом вузе: Сб. научн. тр. VII Междунар. науч.-метод. конф. СПб.: СПбГУ, 2019. С. 54-57.

2. Газета.Ru. URL: https://www.gazeta.ru.

3. Ефимова А.С. Экспрессивный синтаксис в языке СМИ (на материале газетно-публицистического стиля) // Научная сессия ГУАП: Сб. докл. СПб.: СПбГУАП, 2017. C. 133-137.

4. Крылова М.Н. Синтаксическая стилистика прозы Б. Акунина // Наука сегодня: факты, тенденции, прогнозы: Мат. междунар. науч.-практ. конф. Вологда: Маркер, 2016. С. 145-146.

5. Шатилов А.С., Шатилова М.О. Особенности порядка слов в информационных сообщениях (на примере новостных сайтов) // Динамика языковых и культурных процессов в современной России. 2016. № 5. С. 579-584.

6. Элатик А.А. Элементы разговорного синтаксиса в языке современных российских электронных СМИ // Филологические науки. Вопросы теории и практики. 2016. № 10-3 (64). С. 161-168.

(c) Кузина Ольга Васильевна (kuzina85@bk.ru). 